\title{
INFLUENCE OF NATURAL ZEOLITE ON PORTLAND CEMENT HYDRATION PROCESSES AND PROPERTIES OF HARDENED CEMENT PASTE
}

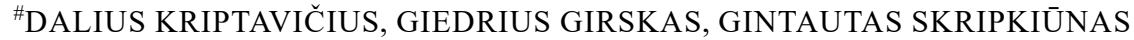 \\ Institute of Building Materials, Vilnius Gediminas Technical University, \\ Sauletekio av. 11, Vilnius, LT-10223, Lithuania \\ ${ }^{\#}$ E-mail: dalius.kriptavicius@vilniustech.lt
}

Submitted May 10, 2021; accepted June 11, 2021

\begin{abstract}
Keywords: Clinoptilolite, Aluminosilicate, Pozzolanic activity, Setting time, Mortar flow, Strength
The application of natural zeolite clinoptilolite ( $\mathrm{Si} / \mathrm{Al}=5.8)$ for substituting up to $20 \mathrm{vol}$. \% of the cement (in mortars) was studied. The effect of the natural zeolite on the consistency and compressive strength at 7, 28 and 90 days was tested at different dosages of clinoptilolite in the mixture. The optimal content (15\% by volume) of the active mineral addition was selected according to the achieved strength results of the mixture and the effect of natural zeolite on the early and late cement hydration was studied. The results of Chapelle test for pozzolanic activity, the initial and final setting times of the paste, thermogravimetric analysis and X-ray diffraction analysis of hardened cement paste showed that natural zeolite clinoptilolite accelerates early and late hydration of cement. No significant differences in calcium hydroxide (CH) content between the specimens modified with clinoptilolite and the specimens containing only ordinary Portland cement (OPC) were observed, despite the high pozzolanic activity of the zeolite.
\end{abstract}

\section{INTRODUCTION}

Global demand for cement is constantly growing, production volumes are increasing and, greenhouse gas emissions are increasing along with expanding production and consumption. The global cement production has increased by about $25 \%$ over the last decade [1]. With an estimated $0.9 \mathrm{~kg}$ of $\mathrm{CO}_{2}$ emitted per one $\mathrm{kg}$ of cement produced [2], the cement industry is responsible for around $5 \%$ of greenhouse gas emissions [3]. Fortunately, certain initiatives, such as the use of alternative fuels and raw materials, pozzolanic additives that make it possible to reduce clinker content in the total cement mass, etc., have reduced the impact of cement production on the global warming. Nevertheless, it is necessary to continue looking for techniques, methods, technologies, materials that would reduce energy demand at all stages of cement manufacturing, including the extraction of raw materials, extend the life cycle of cement concrete, to look for alternative materials and/or additions that can reduce the clinker-to-cement ratio.

Natural zeolites could be used as an alternative to artificial pozzolanic materials. Zeolites are silicates having a framework structure and consisting of two main chemical elements - silica and aluminium - that together with the linked oxygen atoms form the initial tetrahedral units. $\mathrm{SiO}_{4}$ or $\mathrm{AlO}_{4}$ tetrahedra repeat in three directions to fill the space through siloxane $\mathrm{Si}-\mathrm{O}-\mathrm{Si}$ or aluminium siloxane Al-O-Si bonds on all four common angles and form an infinite three-dimensional honeycomb-shaped zeolite framework. The secondary building unit of tetrahedra is a cage with cavities, which create an open and constant structure of internal channels and pores that accommodate $\mathrm{Na}^{+}, \mathrm{K}^{+}, \mathrm{Ca}^{2+}$ and less frequently $\mathrm{Li}^{+}$, $\mathrm{Mg}^{2+}, \mathrm{Sr}^{2+}$ and $\mathrm{Ba}^{2+}$ cations, which balance the electric charges [4].

Zeolites of heulandite group are the most common and widely used natural zeolites. Zeolites of this group are classified as clinoptilolite $\left((\mathrm{Na}, \mathrm{K})_{6} \mathrm{Al}_{6}\left(\mathrm{Si}_{30} \mathrm{O}_{72}\right) \times 20 \mathrm{H}_{2} \mathrm{O}\right)$ and heulandite $\left((\mathrm{Na}, \mathrm{K}) \mathrm{Ca}_{4}\left(\mathrm{Al}_{9} \mathrm{Si}_{27} \mathrm{O}_{72}\right) \times 24 \mathrm{H}_{2} \mathrm{O}\right)$. As their chemical composition is similar, they are classified according to the $\mathrm{Si} / \mathrm{Al}$ oxide ratio. Heulandites have the $\mathrm{Si} / \mathrm{Al}<4$ ratio and clinoptilolites have the $\mathrm{Si} / \mathrm{Al}>4$ ratio. Both minerals are $\mathrm{C} 2 / \mathrm{m}$ group monoclinic crystals with the following crystal lattice parameters: $\mathrm{a}=17.70 \AA$, $\mathrm{b}=17.94 \AA, \mathrm{c}=7.42 \AA, \mathrm{b}=116^{\circ} 24^{\circ}$ (heulandite) and $\mathrm{a}=17.62 \AA, \mathrm{b}=17.91 \AA, \mathrm{c}=7.39 \AA, \mathrm{b}=116^{\circ} 18^{\circ}$ (clinoptilolite) [5].

Natural zeolites are well-crystallized minerals. Despite their almost ideal crystalline structure, their pozzolanic activity is almost as high as that of mineral additives with amorphous structure [6]. Therefore, they could be used as a natural pozzolanic material to replace parts of Portland cement (e.g., in CEM class IV cement according to EN 197-1).

According to the authors who investigated the influence of clinoptilolite on cement pastes, the compressive strength of hardened cement paste cured for 28 days under standard conditions is approx. $15 \%$ higher when $8 \%$ or 16 wt. $\%$ of cement is replaced by natural zeo- 
lite $(\mathrm{Si} / \mathrm{Al}=5.0)$ [7]. Other authors report that the compressive strength of cement-based mortar modified with 20 wt. $\%$ of zeolite $(\mathrm{Si} / \mathrm{Al}=5.9)$ is $33 \%$ lower at 7 days and $7 \%$ higher at 28 days [8]. Authors of the study on the effect of natural zeolite $(\mathrm{Si} / \mathrm{Al}=5.0)$ on the early hydration of cement-based composites report that the replacement of cement by $8 \%$ of zeolite leads to $17 \%$ higher strength at 7 days and $12 \%$ higher strength at 28 days [9]. A group of authors who investigated the effect of $10 \mathrm{wt}$. \% addition of natural zeolite setting time accelerated from $218 \mathrm{~min}$ to $112 \mathrm{~min}$ and the final setting time shortened from $245 \mathrm{~min}$ to $185 \mathrm{~min}$ [11].

Considering all of this evidence, it seems that after 7 days of curing natural zeolites reduce the compressive strength of cement-based composites, i.e. The pozzolanic activity is either absent or it is too low to compensate the reduced content of cement. After 28 days of curing, a greater or lesser increase in the strength is achieved with different content of clinoptilolite added. The studies on the binding processes of cement pastes also suggest that zeolite accelerates the early (up to three days) hydration of cement. All of the studies reviewed here indicate that the influence of natural zeolite on cement hydration and the formation of new compounds have been investigated to a large extent. However, the authors report different results because the effect of zeolites depends on multiple factors, such as particle size, specific surface area, $\mathrm{Si} / \mathrm{Al}$ ratio, chemical and mineral compositions, solubility in alkaline medium, etc. [12]. Therefore, further detailed research is necessary for a better understanding of the effect of natural zeolites in cement hydration process.

\section{EXPERIMENTAL}

Portland cement CEM I 42,5R produced by $\mathrm{AB}$ Akmenes cementas complying with EN 197-1 requirements was used for the preparation of cement pastes and mortars. The amounts of minerals contained in the cement clinker is presented in Table 1 (without gypsum), and main properties in Table 3.

Table 1. Mineral composition of cement clinker.

\begin{tabular}{lc}
\hline Mineral name & $\begin{array}{r}\text { Quantity } \\
\text { (wt. \%) }\end{array}$ \\
\hline Tricalcium silicate & 57.80 \\
$\beta$-dicalcium silicate & 22.15 \\
Tricalcium aluminate & 6.65 \\
Tetracalcium aluminoferrite & 13.40 \\
\hline
\end{tabular}

The natural zeolite from Transcarpathian region in Western Ukraine is composed of clinoptilolite, heulandite and cristobalite (Figure 1). The amounts of oxides in cement and natural zeolite are presented in Table 2. Zeolite has a green colour, the average particle size is bigger than that of cement, the distribution curve is smoother (Figure 2), and the particles are of irregular angled shape (Figure 3).

Polycarboxylate polymer-based superplasticizer was used to control the consistency of the mortars. Characteristics of the superplasticizer: active substance content $28 \%, \mathrm{pH} 4.4 \pm 1$, density $1060 \pm 20 \mathrm{~kg} \cdot \mathrm{m}^{-3}$. Sand fraction was $0 / 2 \mathrm{~mm}$, fineness modulus of sand was 2.11 . The sand was dried at $110 \pm 5^{\circ} \mathrm{C}$ before mixing.

The pozzolanic activity of natural zeolite was determined by the modified Chapelle test according to the

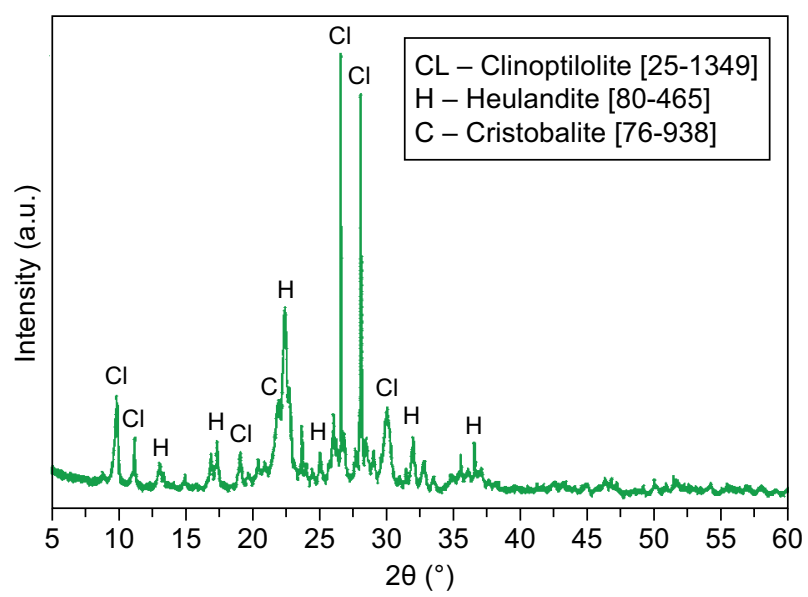

Figure 1. XRD pattern and identified phases of natural zeolite.

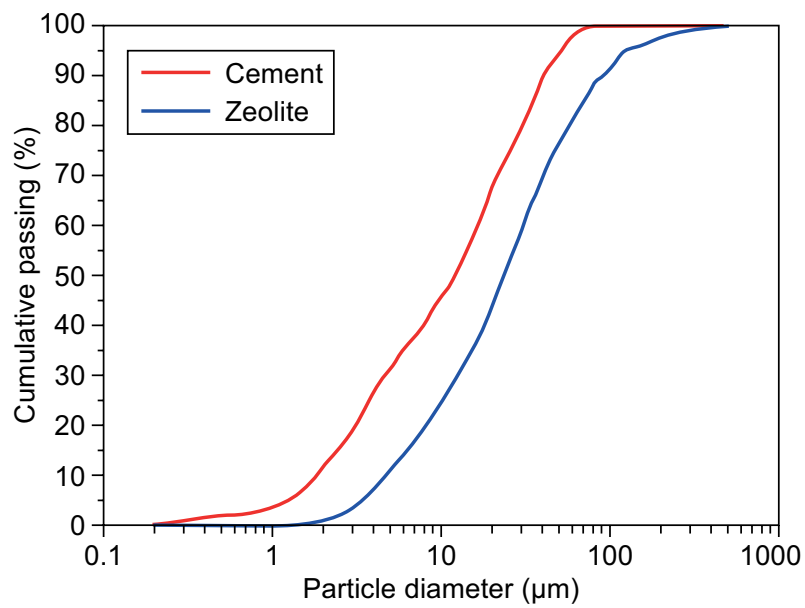

Figure 2. Cement and zeolite particle size distribution.

Table 2. Chemical compositions of cement and natural zeolite.

\begin{tabular}{lrrrrrrrrr}
\hline \multirow{2}{*}{ Material } & $\mathrm{C}$ & \multicolumn{7}{c}{ Oxide content (wt. \%) } \\
\cline { 2 - 10 } & $\mathrm{CaO}$ & $\mathrm{SiO}_{2}$ & $\mathrm{Al}_{2} \mathrm{O}_{3}$ & $\mathrm{Fe}_{2} \mathrm{O}_{3}$ & $\mathrm{MgO}$ & $\mathrm{SO}_{3}$ & $\mathrm{~K}_{2} \mathrm{O}$ & $\mathrm{Na}_{2} \mathrm{O}$ & LOI \\
\hline Cement & 61.4 & 19.5 & 5.0 & 3.1 & 3.9 & 2.5 & 1.1 & 0.1 & 3.4 \\
Zeolite & 3.3 & 72.5 & 12.5 & 1.7 & 0.6 & - & 3.6 & 0.2 & 5.6 \\
\hline
\end{tabular}


French standard NFP 18 513:2012, Annex A. 0.1 N HCl and $0.1 \%$ phenolphthalein dissolved in $50 \%$ alcohol was used as an indicator. The test was conducted twice i.e. with and without the pozzolanic addition. The decrease in the concentration of calcium hydroxide $(\mathrm{CH})$ solution was determined by titration and the amount of $\mathrm{CaO}$ that can be bound by $1 \mathrm{~g}$ of active mineral addition was calculated. The precision of the method is $\pm 10 \%$.

Thermogravimetric and differential thermal analysis (registration of DTA curves) was conducted by the simultaneous thermobalance Linseis STA PT-1600. A corundum crucible with a sample of 50 - $60 \mathrm{mg}$ was heated in air environment up to $1000{ }^{\circ} \mathrm{C}$. Temperature rising rate was $10^{\circ} \mathrm{C} \cdot \mathrm{min}^{-1}$.

The amount of calcium hydroxide formed was calculated by normalising the data according to cement content in the mixtures, i.e. after having evaluated the effect of cement dilution.

Table 3. Cement and zeolite physical properties.

\begin{tabular}{lcc}
\hline Physical properties & $\begin{array}{c}\text { Cement } \\
\text { CEM I 42,5R }\end{array}$ & $\begin{array}{c}\text { Natural } \\
\text { zeolite }\end{array}$ \\
\hline Specific density $\left(\mathrm{kg} \cdot \mathrm{m}^{-3}\right)$ & 3150 & 2570 \\
Blaine fineness $\left(\mathrm{m}^{2} \cdot \mathrm{kg}^{-1}\right)$ & 380 & 144 \\
Median particle size $(\mu \mathrm{m})$ & 17.6 & 26.8 \\
\hline
\end{tabular}

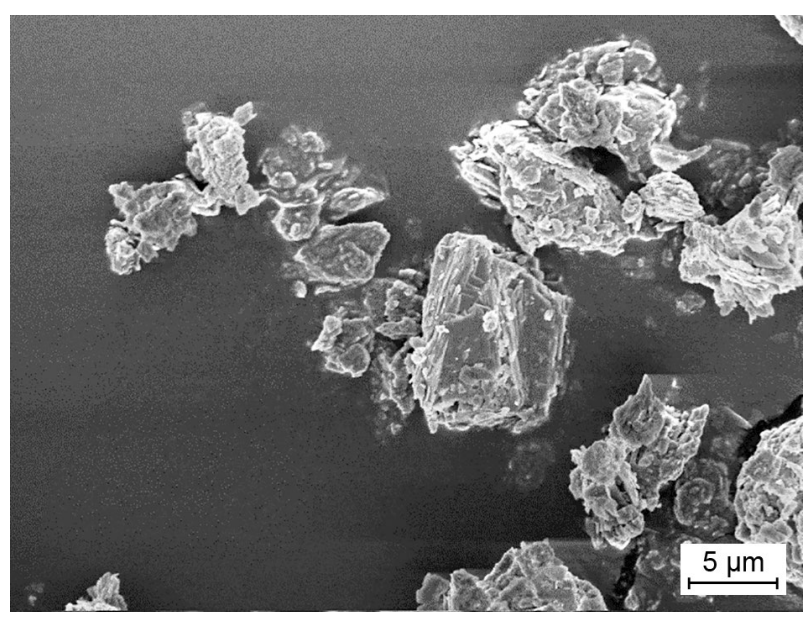

a)
Mineral composition analysis was done by X-ray diffraction meter SmartLab (Rigaku) with a $9 \mathrm{~kW}$ rotating $\mathrm{Cu}$ anode $\mathrm{X}$-ray generator. The radiograms were done in 2 $\theta-10-60$ degree interval by using an optical system adjusted to Bragg-Brentano method, the sample rotating at 0.02 degree and the detector rotating at 1 degree per minute. Software PDXL (Rigaku) and the database of crystal structures PDF-4+ (2019) was used for the analysis.

Mortars were mixed according to the standard method prescribed by EN 480-1 "Reference concrete and reference mortar for testing". The specimens were formed in metal moulds of dimensions $40 \times 40 \times 160 \mathrm{~mm}$. The mortar was poured in two layers and compacted on the vibration table. The prisms were conditioned for 24 hours in the forms at $20 \pm 2{ }^{\circ} \mathrm{C}$, demoulded afterwards and further cured in water at similar temperature. Cement pastes were mixed according to the standard method prescribed by EN 196-3 "Determination of setting times and soundness", the specimens were formed in hermetic polyethylene bags and cured in the same conditions as mortars.

The ratio of cement to zeolite in cement-based mortar mixtures was converted by used materials densities; water to binder ratio was 0.5 ; sand to binder ratio was $3: 1$; superplasticizer was added at $0.8 \%$ by weight

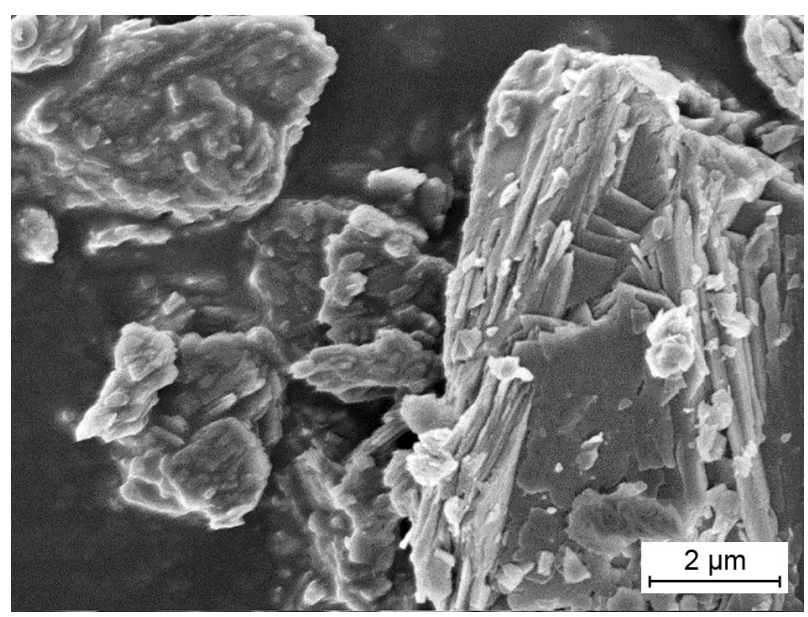

b)

Figure 3. SEM images of natural zeolite particles. a) $\times 3000$, b) $\times 10000$.

Table 4. Compositions of cement mortars (for $1 \mathrm{~m}^{3}$ mixture volume).

\begin{tabular}{lccccc}
\hline \multirow{2}{*}{ Material } & \multicolumn{3}{c}{ Designation of mixtures } \\
\cline { 2 - 6 } & ZL0 (control) & ZL5 & ZL10 & ZL15 & ZL20 \\
\hline Cement (kg) & 512.9 & 487.3 & 461.6 & 436.0 & 410.4 \\
Zeolite (vol. \%) & 0 & 5 & 10 & 15 & 20 \\
Zeolite (kg) & - & 19.3 & 38.6 & 57.9 & 77.2 \\
Water (kg) & 256.5 & 256.5 & 256.5 & 256.5 & 256.5 \\
Sand (kg) & 1538.8 & 1538.8 & 1538.8 & 1538.8 & 1538.8 \\
Superplasticizer (kg) & 4.1 & 4.1 & 4.1 & 4.1 & 4.1 \\
\hline
\end{tabular}

Ceramics - Silikáty 65 (3) 247-254 (2021) 
of cement. The cement pastes were formed at cement/ zeolite ratio 100:0 and 85:15, water/binder ratio 0.5.2.561 volume samples of cement mortar were mixed with the composition presented in Table 4.

The consistence of the mortars was determined by flow table method according to EN 1015-3. The initial and final setting time of the cement pastes was determined according to EN 196-3. The compressive strength of the mortars was determined according to EN 1015-11.

\section{RESULTS AND DISCUSSION}

Pozzolanic activity

The pozzolanic activity is the ability of aluminosilicate minerals to react with calcium hydroxide and form compounds that are very close in composition and properties to the calcium hydrosilicates formed during the hydration of cement clinker minerals [16]. The pozzolanic activity of natural zeolites depends on such factors as the specific surface area, chemical composition, mineral structure, $\mathrm{Si} / \mathrm{Al}$ molar ratio [17]. The pozzolanic activity in this study was determined by a modified Chapelle method. The zeolite used for the tests was found to have a high pozzolanic activity of $0.78 \mathrm{~g} / \mathrm{g}$. The pozzolanic activity values declared in similar tests done by other researchers were $0.64 \mathrm{~g} / \mathrm{g}$ [10] or $0.56 \mathrm{~g} / \mathrm{g}$ [18]. Comparing natural zeolite with artificial pozzolanic materials, it should be noted that microsilica and metakaolin have higher pozzolanic activity.

\section{Technological and mechanical parameters of the mortars}

At 7 days the specimens, except for those modified with $5 \%$ of natural zeolite, had a lower compressive strength compared to the control specimens. After 28 days of curing the specimens modified with $15 \%$ of zeolite had $25 \%$ higher compressive strength. After 90 days a similar trend was observed. Hence, the specimens, where $15 \%$ of cement was replaced with zeolite, demonstrated

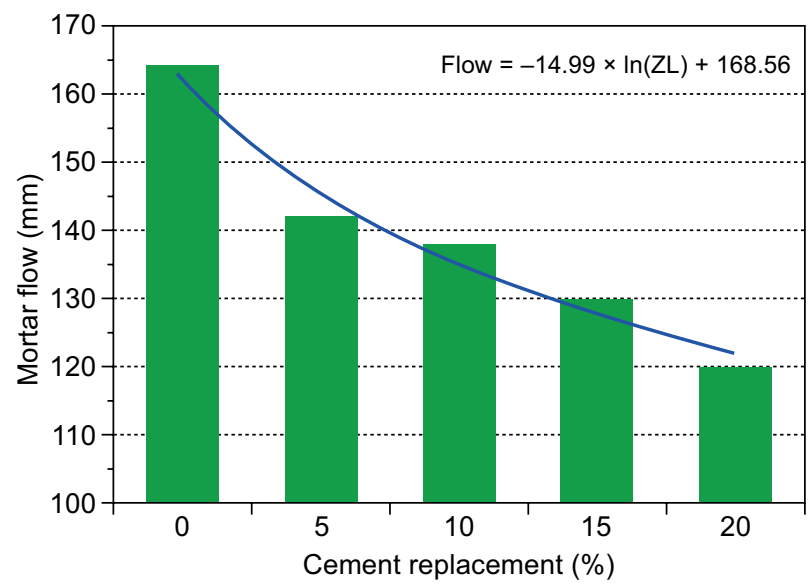

Figure 4. Cement mortars flow. the growth in strength up to $25 \%$, whereas the specimens containing $20 \%$ of zeolite had a lower compressive strength. Figure $5 \mathrm{~b}$ illustrates a normalised compressive strength, i.e. the strength converted to unit weight of cement in mortar mixture. From this point of view, it can be stated that zeolite accelerates the hydration of tricalcium silicate [14] and increases the density of $\mathrm{C}-\mathrm{S}-\mathrm{H}[15]$; thus, higher strength values per unit weight of cement are achieved.

As specimens containing $15 \%$ of zeolite showed the biggest compressive strength increment at 28 and 90 days, further tests were carried out with cement-based concrete with cement/zeolite ratio 85:15\%(v/v).

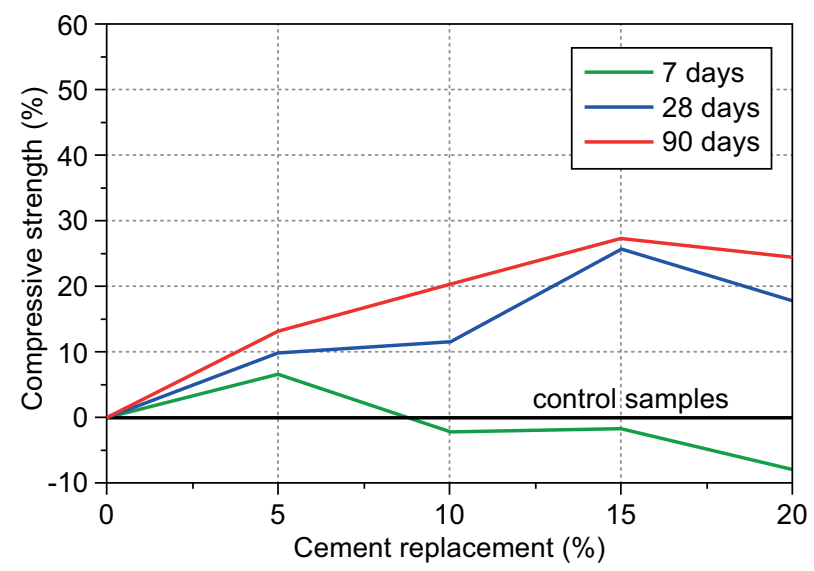

a)

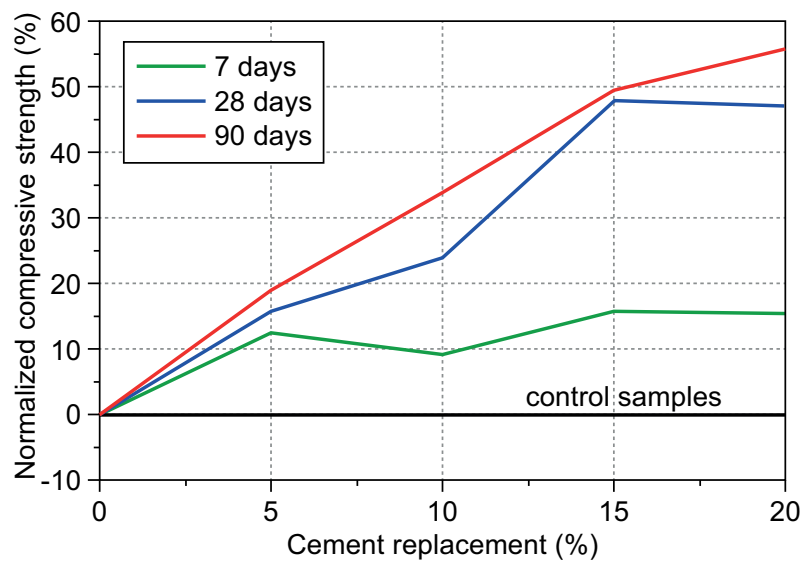

b)

Figure 5. Compressive strengths of cement mortars: a) actual, b) converted to unit weight of cement in mortar mixture.

\section{Initial and final setting time}

The tests showed that natural zeolite affects the initial and final setting time of cement pastes. The results presented in Table 5 show that the setting of specimens modified with $15 \%$ of zeolite started 30 minutes earlier and finished 45 minutes earlier than in unmodified Portland cement paste specimens. 
Similar influence of clinoptilolite was also reported by other authors, who observed that natural zeolite accelerates $\mathrm{C}_{3} \mathrm{~S}$ hydration reactions in the early hydration phase [14]. This effect is explained by a faster dissolution of $\mathrm{C}_{3} \mathrm{~S}$ through a thinner or less dense $\mathrm{C}-\mathrm{S}-\mathrm{H}$ layer built

Table 5. Setting time of cement pastes.

\begin{tabular}{lcc}
\hline Parameter & CEM & CEM + ZL (15) \\
\hline Initial setting time (min) & 240 & 210 \\
Final setting time (min) & 345 & 300 \\
\hline
\end{tabular}

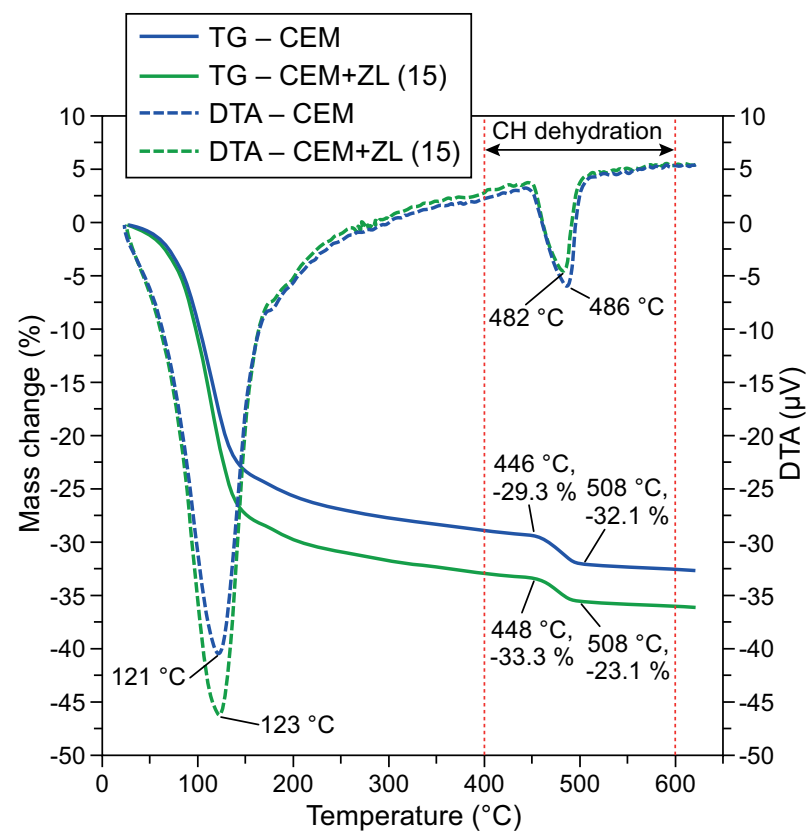

a)

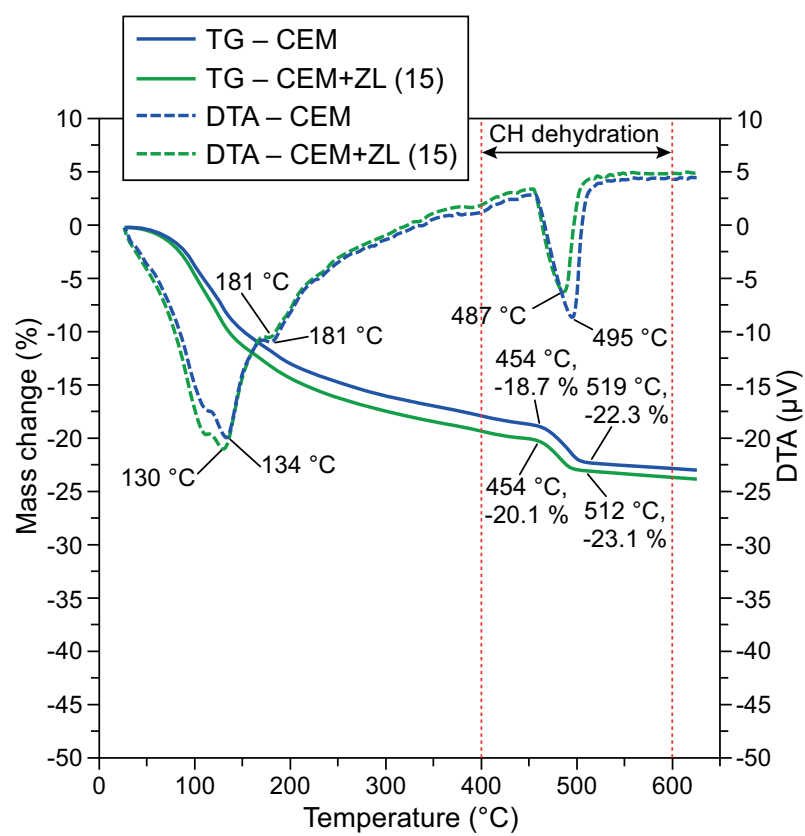

b) on $\mathrm{C}_{3} \mathrm{~S}$ grains [19]. A higher dosage of zeolite in the binder increases the heat of hydration generated during the pre-induction and induction period lasting approx. 4 hours. This is reflected by a vigorous reaction of tricalcium aluminate $\left(\mathrm{C}_{3} \mathrm{~A}\right)$ and a faster rate of dicalcium silicate $\left(\mathrm{C}_{3} \mathrm{~S}\right)$ reaction in the pastes with a higher zeolite content in the binder [20]. Cement mixes with a high content of clinoptilolite tuff demonstrated faster initial and final setting times compared to the OPC. This fact may be related to consistency loss resulting from high water absorption of zeolite particles indicated by high water demand of blended cements to achieve the same consistency as in non-blended systems [11].

Some researchers point out that cement hydration reactions accelerate immediately when the surface of zeolite particles gets wet during mixing. It means that zeolite has a direct influence on hydration processes from the very beginning [21]. By absorbing a lot of water, it can increase the alkalinity of the solution and accelerate the solubility of clinker minerals. The influence is indirect in later stages because calcium hydroxide solution initiates the surface-controlled hydrolysis of the zeolite and the precipitation of C-S-H gel on the zeolite surface [22].

\section{Evaluation of pozzolanic effect by TG and XRD analysis}

The thermogravimetric analysis (TGA) method is commonly used to assess the degree of hydration of Portland cements and to determine the bound water and $\mathrm{Ca}(\mathrm{OH})_{2}$ content from the difference between the mass losses of the samples dried at $105{ }^{\circ} \mathrm{C}$ and at $1000{ }^{\circ} \mathrm{C}$.

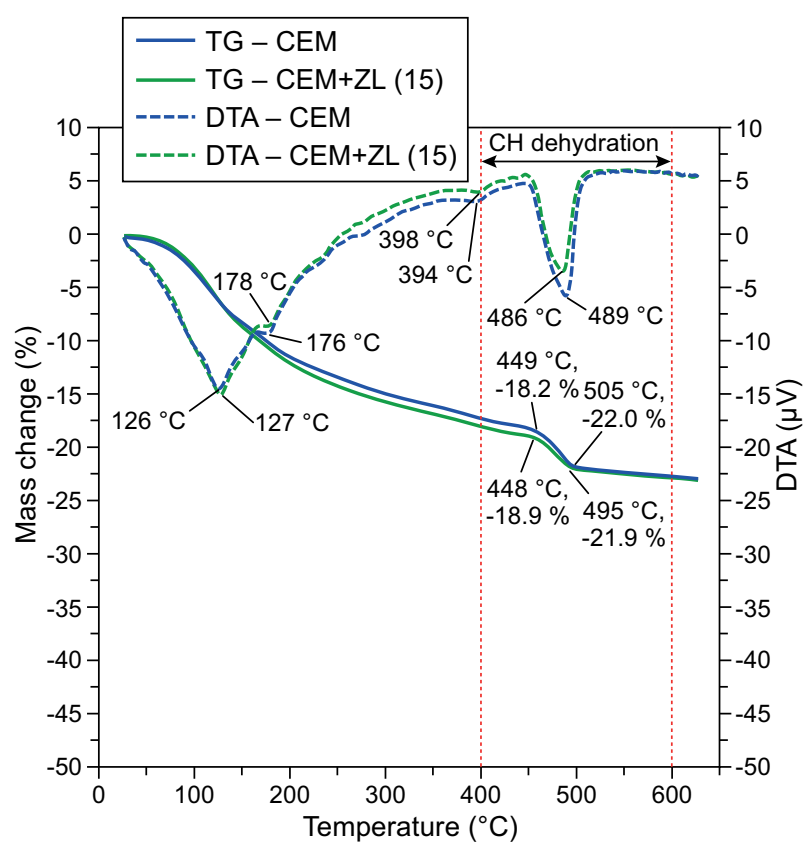

c)

Figure 6. Thermogravimetry curves: a) after 7 days, b) after 28 days, c) after 90 days. 
The mass loss at the temperature up to $\approx 600{ }^{\circ} \mathrm{C}$ in cement-based systems is commonly related to the loss of water, whereas the mass loss at the temperature $600{ }^{\circ} \mathrm{C}$ and above relates to the release of $\mathrm{CO}_{2}$ [23]. According to one of the many authors [13], the dehydration of $\mathrm{CH}$ takes place between 400 and $600{ }^{\circ} \mathrm{C}$.

The results of the calculated amounts of $\mathrm{CH}$ formed are presented in Table 6 taking into account the cement dilution effect. Strange at it may seem, irrespective of the high $(0.78 \mathrm{~g} / \mathrm{g})$ pozzolanic activity of the zeolite determined by Chapelle test at 7 and 28 days, the $\mathrm{CH}$ amounts formed differ only in the range from 5.8 to $7.0 \%$ accordingly. At 90 days the difference of hydration product $\mathrm{CH}$ is $\sim 11 \%$. There is no obvious evidence proving a significant reduction of $\mathrm{CH}$ during the pozzolanic reaction. In terms of strength, however, there is an obvious increase $(\sim 25 \%)$ in the compressive strength observed in the tests of cement-based mortars with the same binder content. This strength increase becomes even more significant when the test results are converted to the strength per unit of weight of cement in the mix.

This striking effect of zeolite has been reported by authors, who claim that if zeolite absorbs the alkali dissolved in water during cement hydration, the stimulating effect of hydration reactions continues and may influence the compressive strength growth without a sig- nificant decrease of $\mathrm{CH}$ content in the cement matrix [9]. It should also be noted that Figure 6 illustrates the increased endothermic effect in the specimen with natural zeolite at $\sim 130{ }^{\circ} \mathrm{C}$, whereas in OPC specimen the increased endothermic effect is within the limits of $\mathrm{CH}$ thermal decomposition. It is a very likely confirmation of a pozzolanic reaction. On the one hand, there is an increase of $\mathrm{C}-\mathrm{S}-\mathrm{H}$ content in the zeolite modified specimen; on the other hand, there is a more expressed $\mathrm{CH}$ decomposition in OPC specimen.

Some authors reporting similar test results state that hydrated cement-zeolite blends are characterized by lower $\mathrm{CH}$ contents and smaller amounts of $\mathrm{C}_{3} \mathrm{~A}$ reaction products compared to Portland cement hydration reaction products [11]. According to other authors, the intensity of $\mathrm{CH}$ peaks lowers with a higher zeolite content in the mix to the dilution effect. When the mixture contains relatively small amounts of zeolite ( $8 \%, 16 \%$, and $24 \%$ ), the high intensity of $\mathrm{CH}$ peaks between 7 and 28 days indicates a minor reaction of $\mathrm{CH}$ with clinoptilolite [9]. Other authors have found that in specimens modified with $10-20 \%$ of zeolite the $\mathrm{CH}$ content at 28 days is $14-23 \%$ lower than in OPC specimens. Based on TGA data, the difference is $19-34 \%$ at 360 days [24]. Researchers of tricalcium silicate hydration kinetics report that the decrease of the dissolution reactive interface can also

Table 6. Results of calculation of $\mathrm{CH}$ amounts ( $\mathrm{mg} \cdot \mathrm{mg}^{-1}$ cement).

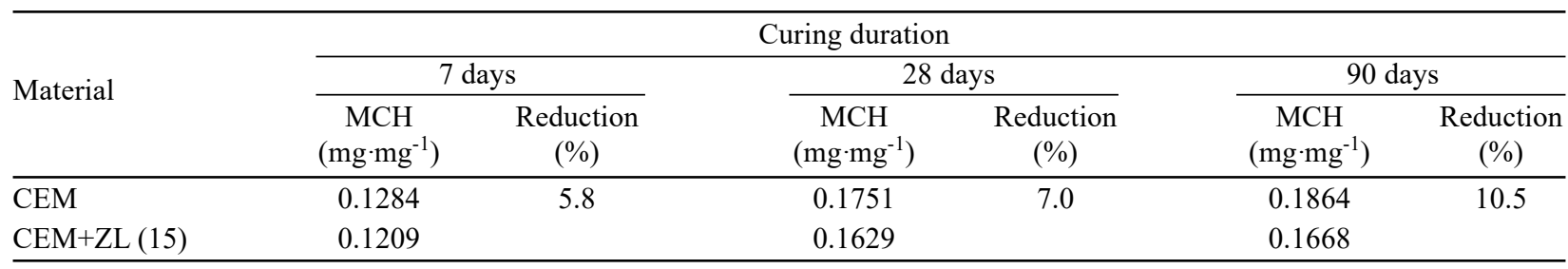

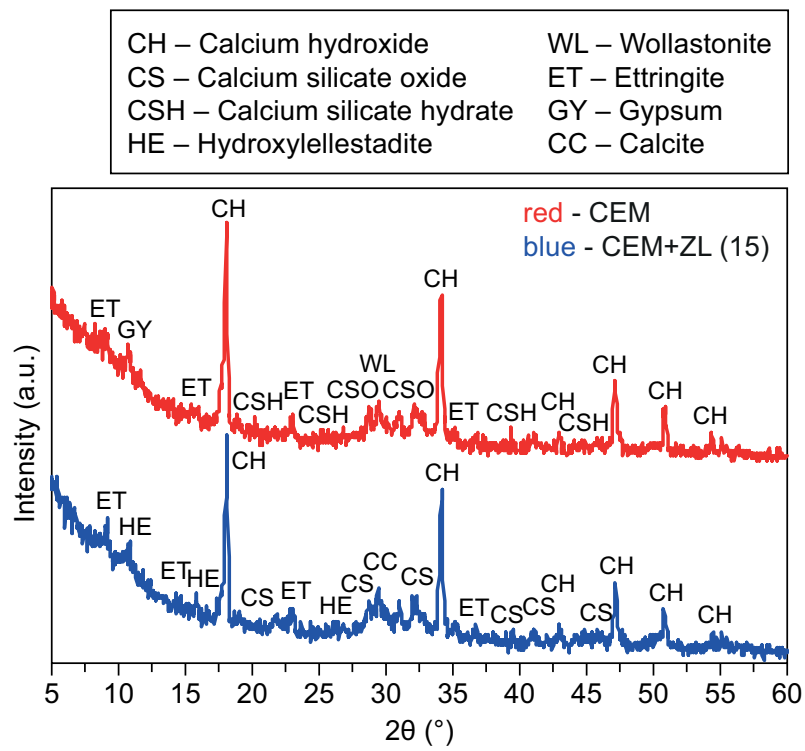

a)

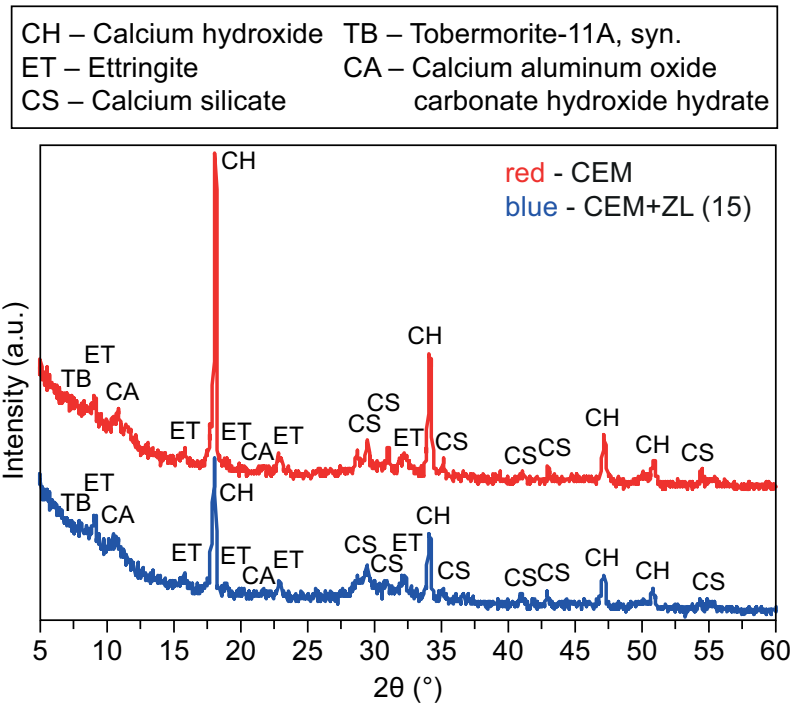

b)

Figure 7. XRD pattern and identified phases: a) after 28 days, b) after 90 days. 
result from the expected decrease of the overall grain surface area. Authors find it possible that the reaction rate limitation at the $\mathrm{C}_{3} \mathrm{~S}$-solution interface is caused by the precipitation of $\mathrm{C}-\mathrm{S}-\mathrm{H}$ onto the $\mathrm{C}_{3} \mathrm{~S}$ surface [25].

The zeolite used for the tests contained mainly calcium, which forms a more stable structure of clinoptilolite compared to the structures of zeolites where other alkaline elements, such as sodium or potassium [26], prevail. A more stable structure means that zeolite dissolves slower in the alkaline environment. Since zeolite grains act as crystallization centres for the newly formed gel, the dissolution processes discontinue and give way to much slower diffusion processes, making the extension of the pozzolanic effect highly probable.

These findings suggest that the growth of compressive strength results from the effect of zeolite on the hydration of $\mathrm{C}_{3} \mathrm{~S}$ and $\mathrm{C}_{2} \mathrm{~S}$ leading to higher $\mathrm{C}-\mathrm{S}-\mathrm{H}$ contents (explains higher compressive strength values) and more $\mathrm{Ca}(\mathrm{OH})_{2}$ produced and used for the pozzolanic reaction; however, TGA tests do not provide this specific evidence.

According to literature sources, hydrated zeolite and cement blends have lower $\mathrm{Ca}(\mathrm{OH})_{2}$ contents and smaller amounts of calcium aluminate $\left(\mathrm{C}_{3} \mathrm{~A}\right)$ hydration products [27] than hydrated OPC. XRD patterns described in research papers, especially the development of $\mathrm{Ca}(\mathrm{OH})_{2}$ peaks, propose a new way of stimulating cement hydration (in the presence of fillers) [28].

The X-ray images of hardened cement paste reveal that a higher content of clinoptilolite does not give rise to substantive differences in the production of new hydration products. The main differences in the minerals formed are visible the most after 28 days of hydration. In our opinion, these differences are caused by the indirect effect of the natural zeolite, i.e. since the zeolite accelerates the hydration of the cement clinker minerals, we compare cement-based matrices that have reached different degrees of hydration.

XRD patterns obtained in our tests confirmed the TGA results, showing that at 7 and 28 days there are no $\mathrm{Ca}(\mathrm{OH})_{2}$ related differences in OPC and modified by $15 \%$ of zeolite cement matrices. A significant decrease in $\mathrm{Ca}(\mathrm{OH})_{2}$ peaks is seen only at 90 days, although TGA data did not show any significant reduction in $\mathrm{CH}$ content.

\section{CONCLUSIONS}

Natural zeolite accelerates early and late hydration reactions of tricalcium silicate seen from earlier initial and final setting times and compressive strength values at 28 days in cement pastes modified with $15 \%$ of natural zeolite. The conversion of compressive strength results shows that natural zeolite significantly increases cement efficiency because, irrespective of cement dilution, the mixes with a lower cement content develop a higher strength.
Natural zeolite is characterised by a high pozzolanic activity, which, by the content of $\mathrm{CH}$ in the cement matrix, becomes obvious only after 90 days of curing. It means that the pozzolanic activity of zeolite depends on the sequence of hydration reaction of cement clinker.

These findings suggest that the main cause of delayed pozzolanic reaction is the big particle size, which hinders the solubility of zeolite. Clinker hydration products precipitate on the surface of insoluble zeolite particles causing the solubility processes to be replaced by diffusion processes. Subsequently, the hydration of cement clinker minerals accelerates, but the pozzolanic reactions of natural zeolite slow down.

Further analysis of the influence of natural zeolite on the intensity of hydration reactions of Portland cement minerals requires more detailed studies of cement-based pastes with different distribution of zeolite particle size.

\section{REFERENCES}

1. IEA, (2020). Global cement production, 2010-2019. IEA, Paris. https://www.iea.org/data-and-statistics/charts/globalcement-production-2010-2019

2. Hendriks C.A., Worrell E., Price L., Martin N., Ozawa Meida L. (1999). The reduction of greenhouse gas emissions from the cement industry. Cheltenham, UK, IEA Greenhouse Gas R\&D Programme, Report PH3/7

3. Allwood J.M., Cullen J.M., et al. (2012). Sustainable Materials - With Both Eyes Open. UIT Cambridge, Cambridge

4. Khalid H.R., Lee N.K., Park S.M., Abbas N., Lee H.K. (2018): Synthesis of geopolymer supported zeolites via robust one-step method and their adsorption potential. Journal of Hazardous Material, 353, 522e533. doi: 10. 1016/j.jhazmat.2018.04.049.

5. Gottardi G., Galli E. (1985). Natural Zeolites. SpringerVerlag, Berlin. Doi:10.1007/978-3-642-46518-5

6. Ahmadi B., Shekarchi M. (2010): Use of natural zeolite as a supplementary cementitious material. Cement and Concrete Composites, 32(2), 134-141. doi: 10.1016/j.cemconcomp. 2009.10.006

7. Pavlík Z., Fořt J., Pavlíková M., Kulovaná T., Černý R. (2015). Characterization of cement pastes containing natural zeolite as a pozzolanic admixture. In Applied Mechanics and Materials (Vol. 719, pp. 206-209). Trans Tech Publications Ltd. doi: 10.4028/www.scientific.net/AMM.719720.206

8. Karakurt C., Topçu İ. B. (2011): Effect of blended cements produced with natural zeolite and industrial by-products on alkali-silica reaction and sulfate resistance of concrete. Construction and Building Materials, 25(4), 1789-1795. doi: 10.1016/j.conbuildmat.2010.11.087

9. Rahhal V. F., Pavlík Z., Tironi A., Castellano C. C., Trezza M. A., Černý R., Irassar E. F. (2017): Effect of cement composition on the early hydration of blended cements with natural zeolite. Journal of Thermal Analysis and Calorimetry, 128(2), 721-733. doi: 10.1007/s10973-0166007-4

10. Perraki T., Kontori E., Tsivilis S., Kakali, G. (2010): The effect of zeolite on the properties and hydration of blended 
cements. Cement and Concrete Composites, 32(2), 128-133. doi: 10.1016/j.cemconcomp.2009.10.004

11. Uzal B., Turanli L. (2012): Blended cements containing high volume of natural zeolites - Properties, hydration and paste microstructure. Cement and Concrete Composites, 34, 101-109. doi: 10.1016/j.cemconcomp.2011.08.009

12. Ozen S. (2013). Pozzolanic activity of natural zeolites: mineralogical, chemical and physical characterization and examination of hydration products. Middle East Technical University, Department of Geological Engineering, Ankara, Turkey

13. Inglezakis V.J., Zorpas A.A. (2012). Natural zeolites structure and porosity. In: Inglezakis V.J., Zorpas A.A. (Eds): Handbook of natural zeolites. Bentham Science Publishers. p. 133-146.

14. Snellings R., Mertens G., Cizer Ö., Elsen J. (2010): Early age hydration and pozzolanic reaction in natural zeolite blended cements: Reaction kinetics and products by in situ synchrotron X-ray powder diffraction. Cement and Concrete Research, 40(12), 1704-1713. doi: 10.1016/j.cemconres. 2010.08.012

15. Yu Z., Yang W., Zhan P., Liu X., Chen D. (2020): Strengths, Microstructure and Nanomechanical Properties of Concrete Containing High Volume of Zeolite Powder. Materials, 13(18), 4191. doi:10.3390/ma13184191

16. Yilmaz B., Ertün T., Uçar A., Öteyaka B., Önce G. (2009): A study on the effect of zeolites (clinoptilolite) on volcanic tuff blended cement paste and mortars. Magazine of Concrete Research, 61(2), 133-142. doi: 10.1680/macr.2007. 00147

17. Lea F. M. (1971). The Chemistry of Cement and Concrete, 3rd ed. Chemical Publishing, New York.

18. Perraki T., Kakali G., Kontoleon F. (2003): The effect of natural zeolites on the early hydration of Portland cement. Microporous and Mesoporous Materials, 61(1-3), 205-212. Doi: 10.1016/S1387-1811(03)00369-X

19. Richardson I. G. (2004): Tobermorite/jennite-and tobermorite/calcium hydroxide-based models for the structure of C-S-H: applicability to hardened pastes of tricalcium silicate, $\beta$-dicalcium silicate, Portland cement, and blends of Portland cement with blast-furnace slag, metakaolin, or sili- ca fume. Cement and Concrete Research, 34(9), 1733-1777. doi: 10.1016/j.cemconres.2004.05.034

20. Tydlitat V., Zakoutsky J., Černy R. (2014): Early-stage hydration heat development in blended cements containing natural zeolite studied by isothermal calorimetry. Thermochimica Acta, 582, 53-58. doi: 10.1016/j.tca.2014.03.003

21. Rahhal V., Talero R. (2005): Early hydration of Portland cement with crystalline mineral additions. Cement and Concrete Research, 35(7), 1285-1291. doi: 10.1016/jcemconres. 2004.12.001

22. Snellings R., Mertens G., Elsen J. (2010): Calorimetric evolution of the early pozzolanic reaction of natural zeolites. Journal of Thermal Analysis and Calorimetry, 101(1), 97-105. doi: 10.1007/s10973-009-0449-x

23. Scrivener K., Snellings R., Lothenbach B. (Eds.). (2018). A practical guide to microstructural analysis of cementitious materials. Crc Press.

24. Kontori E., Perraki T., Tsivilis S., Kakali G. (2009): Zeolite blended cements: evaluation of their hydration rate by means of thermal analysis. Journal of Thermal Analysis and Calorimetry, 96(3), 993-998. Doi: 10.1007/s10973009-0056-x

25. Garrault S., Nicoleau L., Nonat A. (2010). Tricalcium silicate hydration modelling and numerical simulations. In: Proceedings of the RILEM International Symposium on Concrete Modelling CONMOD'10, Lausanne, Switzerland, pp. 22-25. doi: 10.13140/RG.2.1.3622.2480.

26. Benning L. G., Wilkin R. T., Barnes H. L. (2000): Solubility and stability of zeolites in aqueous solution: II. Calcic clinoptilolite and mordenite. American Mineralogist, 85(3-4), 495-508. doi: 10.2138/am-2000-0411

27. Lilkov V., Petrov O., Petkova V., Petrova N., Tzvetanova Y. (2011): Study of the pozzolanic activity and hydration products of cement pastes with addition of natural zeolites. Clay minerals, 46(2), 241-250. doi: 10.1180/ claymin.2011.046.2.241

28. Rahhal V., Bonavetti V., Trusilewicz L., Pedrajas C., Talero R. (2012): Role of the filler on Portland cement hydration at early ages. Construction and Building Materials, 27(1), 82-90. doi: 10.1016/j.conbuildmat.2011.07.021 